\title{
Microbial Contamination of Drinking Water and Human Health from Community Water Systems
}

\author{
Nicholas J. Ashbolt
}

Published online: 27 January 2015

(C) The Author(s) 2015. This article is published with open access at Springerlink.com

\begin{abstract}
A relatively short list of reference viral, bacterial and protozoan pathogens appears adequate to assess microbial risks and inform a system-based management of drinking waters. Nonetheless, there are data gaps, e.g. human enteric viruses resulting in endemic infection levels if poorly performing disinfection and/or distribution systems are used, and the risks from fungi. Where disinfection is the only treatment and/or filtration is poor, cryptosporidiosis is the most likely enteric disease to be identified during waterborne outbreaks, but generally non-human-infectious genotypes are present in the absence of human or calf fecal contamination. Enteric bacteria may dominate risks during major fecal contamination events that are ineffectively managed. Reliance on culture-based methods exaggerates treatment efficacy and reduces our ability to identify pathogens/indicators; however, next-generation sequencing and polymerase chain reaction approaches are on the cusp of changing that. Overall, waterbased Legionella and non-tuberculous mycobacteria probably dominate health burden at exposure points following the various societal uses of drinking water.
\end{abstract}

Keywords Water safety plans · HACCP · QMRA · Surrogate $\cdot$ Indicator $\cdot$ Antimicrobial resistance $\cdot$ Enteric pathogen - Opportunistic pathogen · Viruses $\cdot$ Bacteria . Parasitic protozoa $\cdot$ Fungi $\cdot$ Waterborne $\cdot$ Water-based $\cdot$ Risk management

This article is part of the Topical Collection on Water and Health

N. J. Ashbolt $(\bowtie)$

School of Public Health, University of Alberta, Edmonton, Room

3-57D, South Academic Building, Alberta T6G 2G7, Canada

e-mail: ashbolt@ualberta.ca

\section{Introduction}

The provision of safe drinking water has been one of humanity's most successful public health interventions and is a defining aspect of a developed country. Nonetheless, ignorance of the potential risks and inappropriate training of staff and managers working on drinking water systems still results in unnecessary waterborne disease outbreaks in affluent communities $[1 \bullet]$. Furthermore, re-introduction of once-controlled diseases, such as cholera, may rapidly spread during periods of disasters when sanitation systems are non-functional and drinking water treatment is inadequate. A recent example was the Haitian epidemic [2] where, although a developing region, international aid workers introduced the outbreak strain and then tourists spread infections to more developed regions $[3,4 \bullet]$. Hence, to some degree, differentiating pathogen risks between developed regions and those less developed, particularly rapidly developing regions, is artificial and not very useful. Therefore, this review is relevant to most regions with functional drinking water treatment provided through a community system. A key realization is the need for ongoing system-wide vigilance, coupled with a preventative rather than just responsive management approach. This approach is best practiced globally using principles from the food industry's Hazard Analysis Critical Control Point (HACCP) approach, described by the World Health Organization (WHO) as Water Safety Plans (WSPs) $[5,6]$. In addition to existing regulatory framework constraints, this WSP approach may be particularly hard to implement in (developed) regions that have not identified major waterborne outbreaks for decades.

Even with well-operated drinking-water treatment systems, there is growing concern that aging drinking water distribution systems (DWDSs) are vulnerable to higher rates of mains breaks/repairs and related pressure losses that may lead to pathogen intrusion scenarios $[7 \bullet, 8 \bullet]$. Also, traditional endof-pipe compliance monitoring practices may not identify 
short periods of DWDS intrusions or short periods of poorer treatment performance, such as is associated with raininduced dirty-water events that appear to be associated with increased rates of waterborne gastrointestinal disease [9]. Generally, drinking-water gastrointestinal cases are not well quantified, even in developed regions, due to the insensitivities of surveillance and specific epidemiology studies [10, 11]. For the US (with approximately 300 million people) estimates of annual drinking-water gastrointestinal cases range from 12-19 million [12]. In addition, beyond the DWDS is a vast network of building or in-premise plumbing that, under certain conditions, allows the growth and release of waterbased opportunistic pathogens, many resulting in respiratory or skin diseases, such as from Legionella pneumophila and non-tuberculous mycobacteria (NTM) [13]. At least in the US, these water-based pathogens appear to cause a higher health burden via hospitalization than waterborne enteric pathogens [14•]. With the exception of recently enacted regulatory monitoring for Legionella in The Netherlands, France, and Germany, these water-based pathogens are neither targeted nor identified by current regulatory monitoring that focuses on fecal indicator bacteria (FIB) [e.g. Escherichia coli and enterococci]. Due to environmental growth of water-based opportunistic pathogens, quite different but familiar control strategies (elimination of stagnation zones and related temperature and disinfectant control) are required for in-premise plumbing, particularly in healthcare settings [15].

This review builds on previously conducted reviews [5, $16 \cdot, 17-19]$, and is organized around recent findings associated with drinking-water microbial hazards and scenarios that need to be managed as part of a WSP-like system-wide management framework to provide safe drinking water. This information should also be informative for the growing use of quantitative microbial risk assessment (QMRA) to inform WSPs [20]. As such, pathogens are grouped into waterborne (enteric viruses, bacteria, parasitic protozoa, and fungi) and water-based (environmental viruses, bacteria, free-living protozoa, and fungi) groups. Furthermore, crosscutting pathogen issues, such as antimicrobial resistance (AMR) gene transfer and the role of the host microbiome, are introduced.

\section{Waterborne (Enteric) Pathogens}

There are over 500 waterborne pathogens of potential concern in drinking waters, identified by the US Environmental Protection Agency (EPA) through its Candidate Contaminant List ('CCL 3 Universe' list, available at http://www.epa.gov/ safewater/ccl/pdfs/report_ccl3_microbes_universe.pdf). To aid in identifying representatives within each of the microbial groups (viruses, bacteria, parasitic protozoa, and fungi), Table 1 lists current and likely members of importance to manage waterborne risks from community drinking waters.
This subset contains representative members, known as reference pathogens, which are increasingly being used to support WSPs via QMRA, given their general coverage of the vast majority of human health effects associated with pathogens in drinking water [26].

Various counties have developed treatment goals or drinking-water parameters based on microbial risk assessment [5]; however, only in the Netherlands is there a regulatory requirement for drinking-water companies to provide water that, in theory, meets an annual gastrointestinal risk of $<10^{-4}$ $95 \%$ of the time. This means, for example, that drinking water is required to have less than one enteric virus per million liters of drinking water [27], a concentration well below the capabilities of current measurement techniques. Epidemiology studies have shown an increased gastrointestinal risk $(30 \%)$ when enteric virus concentrations were at approximately one genomic copy per liter [28], highlighting the difference between what can be measured directly compared with the low concentrations sought by regulations to control risk of gastrointestinal illness as estimated by QMRA. Hence, estimations of enteric pathogen risks are more reliant upon measuring pathogen concentrations in contaminated source water(s), and using surrogates to estimate treatment removals [29]. As such, QMRA estimates contain uncertainties associated with reference pathogen detection, their relationships to surrogates used, and relevance of limited dose-response models that may not address life-stage of most interest. Therefore, QMRA is probably better used to present relative risks to inform management about different risk scenarios in their considerations for developing WSPs, rather than trying to estimate absolute risk levels.

Key areas not currently addressed in most QMRAs of systems are the DWDS and premise plumbing risks. For both, biofilms on pipe walls and sediments within storage reservoirs and pipes [30] present a sequestering environment for various enteric pathogens, including viruses that are relatively resistant to normal disinfection treatments [31], and allow growth of water-based pathogens [32]. Limited QMRA studies of biofilm enteric pathogen risks are available but results suggest that accumulation of virions, known to occur within DWDSs [28], could present a higher level of risk than background levels when they slough off and re-enter the mass flow to customers [33]. In addition, various free-living protozoa and metazoan feeding within DWDS biofilms may also act as disinfectant-resistance transport hosts for enteric pathogens, including viruses $[34 \cdot, 35]$. The risks associated with waterbased pathogens, of particular relevance to premise plumbing, are discussed latter.

\section{Reference Enteric Viruses}

Human noroviruses cause the most gastrointestinal illness in all regions of the world, with the vast majority thought to be acquired via person-to-person and then by food [36•], given 
Table 1 Recognized and potential enteric and water-based microbial pathogens to manage community drinking water risks

\begin{tabular}{|c|c|c|c|c|}
\hline \multirow{2}{*}{$\begin{array}{l}\text { Microbial } \\
\text { group }\end{array}$} & \multicolumn{2}{|l|}{ Enteric (waterborne) } & \multicolumn{2}{|l|}{ Water-based (opportunistic) } \\
\hline & Recognized & Potential & Recognized & Potential \\
\hline Viral & $\begin{array}{l}\text { Adenovirus } 40 \text { and } 41 \\
\text { Avipolyomavirus }^{\mathrm{a}} \\
\text { Enterovirus } \mathrm{A}-\mathrm{D} \\
\text { Hepatitis A and E } \\
\text { Norovirus } \mathrm{G} 1 \text { and } \mathrm{G} 2 \\
\text { Rotavirus A } \\
\text { Sapovirus } \mathrm{G} 1\end{array}$ & $\begin{array}{l}\text { Mamastrovirus } 1 \\
\text { Orthoreovirus C }\end{array}$ & None & $\begin{array}{l}\text { Mimivirus }^{\mathrm{b}} \\
\text { Mamavirus }^{\mathrm{b}}\end{array}$ \\
\hline Bacterial & $\begin{array}{l}\text { Aeromonas hydrophila } \\
\text { Campylobacter coli } \\
\text { C. jejuni } \\
\text { Salmonella enterica } \\
\quad \text { (non-typhoid) } \\
\text { Shigella sonnei } \\
\text { Vibrio cholerae }\end{array}$ & $\begin{array}{l}\text { Acinetobacter baumannii } \\
\text { Arcobacter butzleri }^{\mathrm{c}} \\
\text { Helicobacter pylori } \\
\text { Clostridium difficile }^{\mathrm{c}} \\
\text { Listeria monocytogenes } \\
\text { Pseudomonas aeruginosa }^{\mathrm{c}} \\
\text { Staphylococcus aureus }{ }^{\mathrm{c}} \\
\text { Yersinia enterocolitica }\end{array}$ & 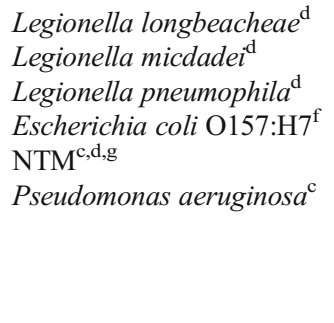 & $\begin{array}{l}\text { Acinetobacter baumannii }{ }^{\mathrm{c}} \\
\text { Aeromonas hydrophila }^{\mathrm{c}} \\
\text { ARB } \text { (Afipia, Bosea, }^{-} \\
\text {Parachlamydia } \text { spp., } \\
\text { Coxiella burnetii) }^{\mathrm{d}} \\
\text { E. coli } \text { (toxigenic strains) }^{\text {Listeria monocytogenes }}{ }^{\mathrm{d}} \\
\text { Staphylococcus aureus }^{\mathrm{c}} \\
\text { Stenotrophomonas maltophilia }^{\mathrm{c}, \mathrm{d}}\end{array}$ \\
\hline Protozoan & $\begin{array}{l}\text { Cryptosporidium hominis } \\
\text { and parvum } \\
\text { Cyclospora cayetanensis } \\
\text { Giardia intestinalis } \\
\text { assemblages A and B } \\
\text { Toxoplasma gondii }\end{array}$ & Blastocystis hominis & $\begin{array}{l}\text { Acanthamoeba T4 } \\
\text { Balamuthia mandrillaris } \\
\text { Naegleria fowleri }\end{array}$ & $\begin{array}{l}\text { Acanthamoeba } \text { spp. }^{\mathrm{d}} \\
\text { Vahlkampfia } \text { spp. }^{\mathrm{d}} \\
\text { Vannella } \text { spp. }{ }^{\mathrm{d}} \\
\text { Vermamoeb }^{\text {vermiformis }}{ }^{\mathrm{d}}\end{array}$ \\
\hline Fungal & $\begin{array}{l}\text { None } \\
\text { Microsporidia (e.g. Encephalitozoon } \\
\quad \text { bieneusi, E. intestinalis) }\end{array}$ & Candida albicans & None & $\begin{array}{l}\text { Aspergillus fumigatus } \\
\text { Aspergillus terreus } \\
\text { Candida albicans } \\
\text { Candida parapsilosis } \\
\text { Exophiala dermatitidis }\end{array}$ \\
\hline
\end{tabular}

$A M R$ antimicrobial-resisting, $A R B$ amoeba-resisting bacteria, $Q M R A$ quantitative microbial risk assessment, $V B N C$ viable but non-culturable, $D W D S$ drinking water distribution systems, NTM non-tuberculous mycobacteria

${ }^{a}$ Main species being JC polyomavirus, which is largely excreted in urine, as it infects the kidneys along with the respiratory system or brain

${ }^{\mathrm{b}}$ Acanthamoeba polyphaga mimivirus (APMV) may cause respiratory disease and unknown health effects from Mamavirus [21]

${ }^{\mathrm{c}}$ Most strains of species from the environment may be non-pathogenic, however there is future potential for AMR strains. For P. aeruginosa, most clinical disease is identified with otitis media, with less severe disease via drinking water aerosols leading to diffuse bronchopneumonia and more severe disease in high-risk children with cystic fibrosis; folliculitis is important directly via drinking waters used in pools/spas

${ }^{\mathrm{d}}$ Largely non-pathogenic amoeba hosts containing ARB, of which many ARB are of key concern, from drinking water [22], except possibly Coxiella burnetii, which is of low theoretical risk estimated by QMRA [23•]

${ }^{\mathrm{e}}$ Cholera may re-emerge if a major event interferes with drinking-water disinfection, and an epidemic strain is introduced from an endemic region of the world

${ }^{\mathrm{f}}$ Shiga toxin and verotoxin-producing E. coli (and various intracellular Salmonella and Listeria) strains may grow within free-living protozoa [24], and non-pathogenic VBNC E. coli in DWDS biofilms [25]

${ }^{\mathrm{g}}$ Various NTM, including Mycobacterium avium (M. intracellulare) complex, M. chelonae, M. fortuitum, M. gordonae, and M. kansasii

the predominance of genogroup II strains implicated. In waterborne cases, genogroup I is normally implicated [37], presumably due to increased environmental robustness. An interesting finding with human noroviruses and the second most common cause of gastrointestinal illness, rotavirus (although greatly diminishing due to childhood vaccination programs), is the need for certain histo-blood group antigen (HBGA) receptors for these pathogens to bind to target cells [38]. Not only do certain gut bacteria have these HBGA binding sites but these bacteria may also facilitate infection, as recently demonstrated with human B cells [39॰]. Therefore, one's gut microbiome and blood group impact the likelihood of infection. Furthermore, there is now optimism that a routine cell culture system for human noroviruses may be developed, which would be of particular value to the water-treatment industry. Non-human, culturable noroviruses, such as murine noroviruses among others, are used as surrogates for treatment performance (inactivation studies) but there is limited understanding of the validity of these surrogates for any human norovirus genogroup or mode of inactivation [40, 41•].

Overall, Norovirus is considered one of the most conservative virus targets for drinking-water QMRA studies (measured 
via reverse transcriptase-quantitative polymerase chain reaction [RT-qPCR])-conservative in that if Norovirus risks are managed, most other enteric viruses will also be controlled. However, there are limited dose-response models to interpret molecular (RT-qPCR) exposure data [42•], noting it is unknown what fraction of virions may be infectious (given that fresh suspensions of virions were used in dose-response studies versus more aged virions typically present in the environment, and that both infectious and non-infectious virions are measured by RT-qPCR). Counteracting the infectious fraction to some unknown degree is virion clumping, which would increase infection likelihood [43]. In the absence of infectivity data, the WHO, as well as various other jurisdictions, recommend culturable rotaviruses as a preferred enteric virus reference, or the environmentally hardier human adenoviruses or reoviruses, which may be in similarly high concentrations as noroviruses in sewage-contaminated waters [44-46]. The problem with using adenoviruses is that gastrointestinal illness is largely caused by serogroups 40 and 41 , whereas the doseresponse model available for QMRA is only for a respiratory strain, and there are limited illness or infection rates known for reoviruses (Orthoreovirus $C$ ) in humans.

Regarding virus surrogates (typically bacteriophages), there is no identified single surrogate known to mimic the various behaviors of different human enteric viruses (with respect to surface charge, hydrophobic interactions, and inactivation by sunlight, disinfectants, etc.). Human adenoviruses provide a good example of a key virus risk and considerations for what surrogate is most suited, being more resistant than Enterovirus or Rotavirus when ultraviolet (UV) disinfection is practiced. Given the expectation for a $4-\log _{10}$ inactivation of surface waters in the US (i.e. $99.99 \%$ ), it is of concern that human adenoviruses are relatively poorly inactivated by so-called low pressure (LP) UV disinfection (monochromatic at $254 \mathrm{~nm}$ ), but readily inactivated with medium pressure (MP), polychromatic UV treatment (including 254, 265, 280 and $295 \mathrm{~nm}$ wavelengths) [47•]. The differences are, in part, thought to arise due to LP-UV targeting nucleic acids, which may be repaired by the host cell, whereas MP-UV also impairs the protein coats of virions, potentially impeding cell infection.

Therefore, consideration of these different modes of inactivation is important when selecting an appropriate surrogate. For example, a commonly used disinfection bacteriophage surrogate, the F-RNA coliphage MS2, demonstrates a 4-log inactivation with $64 \mathrm{~mJ} / \mathrm{cm}^{2}$ LP-UV and $46 \mathrm{~mJ} / \mathrm{cm}^{2}$ MP-UV compared with adenovirus 2 requiring 120 and $45 \mathrm{~mJ} / \mathrm{cm}^{2}$, respectively [47•]. Not only do these LP- and MP-UV systems inactivate bacteriophages by different mechanisms but their host bacterial cells may also use different repair mechanisms (referred to as photoreactivation and dark repair mechanisms). In the case of MS2, there appears to be no repair by the E. coli host, whereas the dsDNA Salmonella bacteriophage PRD1, appears to be the most resistant of four bacteriophages examined, with a
4- $\log _{10}$ reduction (similar for both LP- and MP-UV) requiring $103 \mathrm{~mJ} / \mathrm{cm}^{2}$ with photoreactivation versus only $35 \mathrm{~mJ} / \mathrm{cm}^{2}$ without reactivation [47•]. In general, MS2 is a valid surrogate for chemical disinfection processes but due to its $E$. coli source from various warm-blooded animals, it is not a good index of human enteric virus presence in environmental waters [48].

In summary, human enteric reference viruses include species of the genera Adenovirus, Enterovirus, Norovirus, and Rotavirus, and potentially Orthoreovirus $C$ (a reovirus). Generally, only one or two are chosen but only when there is likely to be a human source of fecal contamination yielding human enteric virus risk. In the absence of a sanitary survey to indicate possible sewage/septic seepage pollution to source waters, or to give a second opinion, human-targeted Bacteroides provide a valuable and potentially more sensitive indicator than assaying for human enteric viruses [49]. In urbanized settings, DWDS intrusions are likely to include human enteric viruses, which may dominate gastrointestinal risks via drinking water [43].

\section{Reference Enteric Bacteria}

The classic waterborne enteric pathogens include Vibrio cholerae (serogroups O1 and O139, causing cholera), Salmonella enterica (subsp. enterica ser. Typhi, causing typhoid), and Shigella spp. (four species causing dysentery), which have largely been controlled by water treatment/disinfection and are therefore rarely an issue via drinking water in developed regions. However, person-to-person and foodborne spread maintains Shigella sonnei within the sewage of developed regions, along with closely-related shiga toxin and verotoxin-producing $E$. coli, and pathogenic species of Campylobacter, Salmonella, Arcobacter, Helicobacter and Yersinia (Table 1). An emerging issue is that of AMR, which may occur within any of the bacterial members listed in Table 1 but is noted here by example for $E$. coli in well waters associated with animal production [50]. These AMR genes may horizontally transfer between commensal and enteric pathogenic bacteria, and present a higher risk due to antimicrobial treatment failures [51•]. Within healthcare facilities, there is also a considerable health burden due to the prevalence of AMR Pseudomonas aeruginosa and Clostridium difficile; with the latter being a spore-former it may persist in sewage and river waters and eventually make its way to drinking waters, and AMR- $P$. aeruginosa may grow post-water treatment (discussed further in the section on "Control of Water-Based Pathogens") [Table 1, potential future concern]. AMR Staphylococcus aureus is also of potential concern via companion animals to water [52] and could be considered a useful reference pathogen for AMR in the future.

The most recognized and useful reference enteric bacteria in developed regions are Salmonella enterica, Campylobacter jejuni, and E. coli $\mathrm{O} 157: \mathrm{H} 7$, each containing human pathogenic strains that vary by fecal source $[53,54]$. However, there 
is limited data on the quantification of these pathogens in source drinking waters (most studies provide presence/ absence data) due to the difficulties in culturing these bacteria from the environment $[31,55]$. Therefore, given the general presence of FIB and their ease of culture, either E. coli or enterococci have been used as surrogates to assess enteric bacterial pathogen removals by treatment barriers. However, there are improvements in risk management if culture-free methods are used, as discussed in the next section.

\section{Non-Culturable States of Enteric Bacteria}

Historically, clinical and environmental microbiology methods have been based on culturing cells on selective media. Today this is still the general situation in clinical laboratories, although next-generation sequencing costs are so rapidly decreasing that single gene to whole metagenomic approaches are enabling rapid and broader detection of pathogens from clinical and environmental samples (Fig. 1). From a water perspective, qPCR assay for Enterococcus spp. (targeting 16S rDNA) was the first molecular method approved by the EPA (for recreational water assessment in treated/sewage-impacted water bodies [57•]). This assay of total (dead or alive) enterococci provides the best index to health risk following fresh (and marine) water exposures in epidemiology studies [58•] (gastrointestinal risk was assumed to be dominated by enteric viruses due to the presence of municipal wastewater contamination). Hence, it would seem appropriate to consider the use of qPCR for enterococci as possibly the most useful microbial index identified to date for sewage-contaminated drinking water. Furthermore, improved detection sensitivity and apparent viability appears possible by qPCR targeting the thousands of copies of $16 \mathrm{~S}$ ribosomal RNA within viable bacterial cells rather than qPCR directed to low-copy-number DNA-based genes [59॰].

As for all possible pathogen infections, we now realize that our health is also reliant upon the 'health' of our microbiomes and, in the case of the gastrointestinal tract, the gutome is being explored by next-generation sequencing approaches. Informed by these metagenomic studies and clinical samples from outbreak cases, the expectation is that many more important, currently uncultured drinking water pathogens (and pathogenvulnerable gutomes) will be identified over the coming decades
Fig. 1 Various cell targets used for non-culture-based methods and culture-based phenotypic methods to detect microorganisms from water (from Sen and Ashbolt [56]). $P F G E$ pulse field gel electrophoresis, $R A P D$ random amplified polymorphic DNA, $A F L P$ amplified fragment length polymorphism, MALDI-TOF matrix-assisted laser desorption/ ionization-time of flight, $N A S B A$ nucleic acid sequence-based amplification, FISH fluorescent in situ, hybridization, $r R N A$ ribosomal ribonucleic acid. *Represents RNA from $18 \mathrm{~S}$ rRNA present in eukaryotes such as protozoa, or 16S rRNA present in bacteria

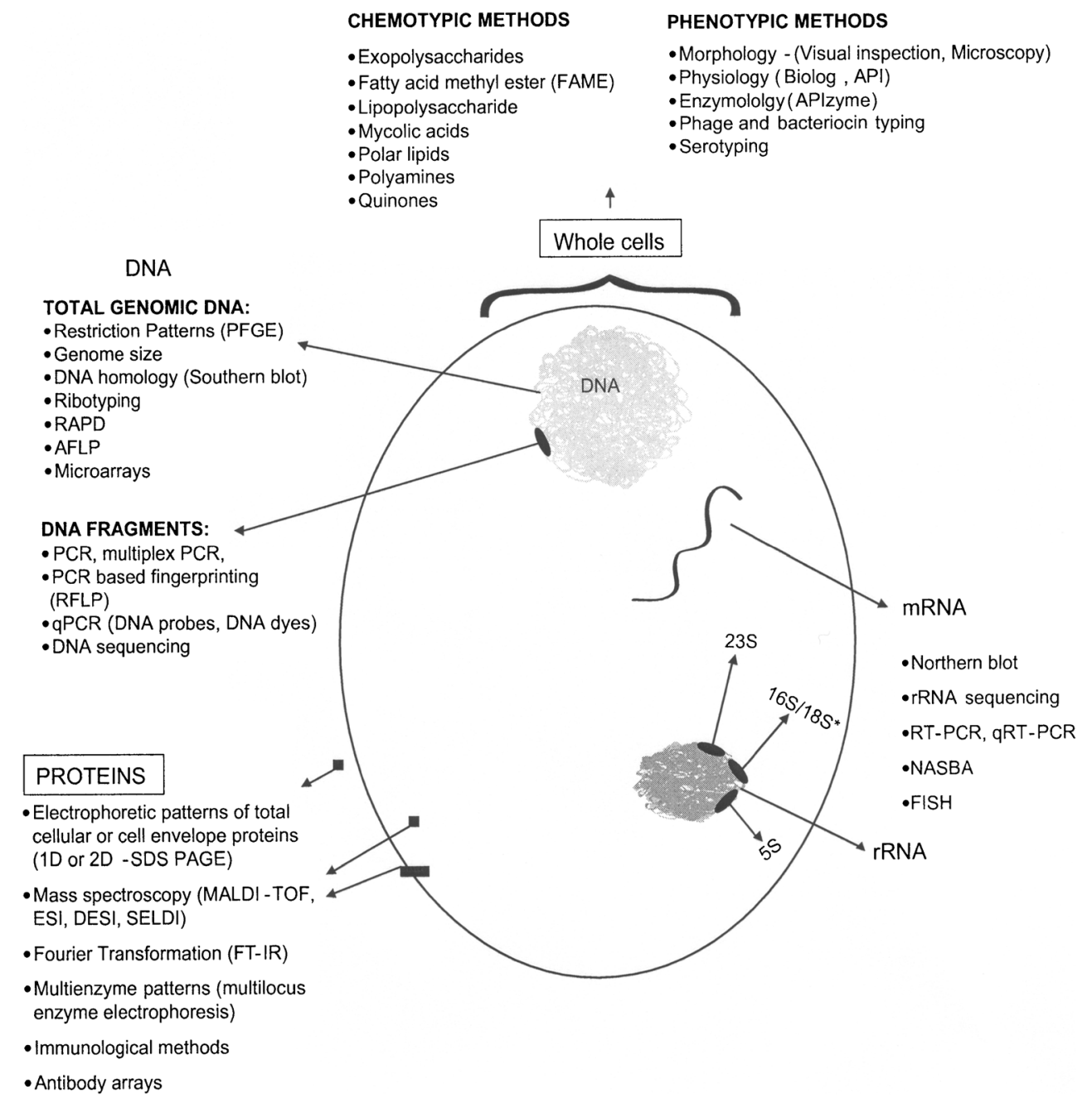


than those listed in Table 1, noting that etiologic agents are identified in less than $45 \%$ of drinking-water outbreaks in the US [16•], in part due to the inability to culture them.

However, even well-known bacterial pathogens lose the ability to be cultured when moved from recent cell growth in the gut to the aquatic environment. Campylobacters are particularly well known for this, forming viable but nonculturable (VBNC) cells [60•]. Whereas the term active but non-culturable (ABNC) makes more sense given the term 'viable' normally refers to the ability to grow an organism, VBNC is used in this review due to the majority of papers on this topic describing these cells as such. The VBNC cell state is important to drinking water and public health due to the potential of VBNC cells to cause infection in humans [61], formed during water disinfection [62], and this has not yet been addressed by current culture-based compliance monitoring of drinking water, nor has the likely environmental biofilm niche for VBNC environmental pathogens been sampled. A further complication (in describing these pathogens as enteric and/or environmental) is that resuscitation of VBNC cells may also occur within environmental (free-living) protozoa-true for a variety of the intracellular enteric pathogens listed in Table 1 [63]. Hence, it is probably more useful to take a microbial ecology perspective and think of the VBNC state as part of the normal lifecycle of most bacteria that do not form spores. As such, various mechanisms have probably evolved over millennia, with their various interactions within aquatic (and subsequently water system) predatory eukaryotic organisms, well before they adapted to the human gut (also true for the FIB, e.g. Enterococcus faecalis [64]).

Of particular relevance to drinking water disinfection, and easily confused with the VBNC state, are highly-resistant cell forms that enable bacterial survival in the presence of stressors, known as persister cells [65]. Unlike VBNC cells, there is always some fraction of persisters in a population present as a reversible non-replicating state, a particular feature of AMR strains. Persisters may represent a few percent of a bacterial population and are more common post-exponential growth [65]. Although not specifically identified, persisters may contribute to the inability to completely disinfect drinking water, seen by various tailing effects in disinfection kinetic studies [66] and the downstream presence of various enteric bacteria identified by molecular methods within drinking water/biofilms, e.g. along with VBNC forms of $E$. coli and Helicobacter pylori $[25,67]$.

H. pylori is a particularly controversial 'waterborne' pathogen due to the presence of non-culturable cells in drinking water. To date, H. pylori has only been detected by molecular methods in drinking waters [67], and it demonstrates a subpopulation able to 'survive' drinking-water chlorination treatment [68], yet there is only weak epidemiologic evidence for waterborne transmission [69]. As with many enteric pathogens, person-to-person spread is probably more important than the waterborne route, yet it remains unclear if $H$. pylori should even be considered waterborne in developed regions.

\section{Reference Parasitic Protozoa and Fungi}

When a parasitic protozoan agent is identified during waterborne outbreaks in the US it was most often due to the presence of cysts to human-infective Giardia intestinalis (synonyms $G$. lamblia and $G$. duodenalis) [16•], further described as assemblages A or B. However, from a European perspective, and globally in developed regions over the last decade, more disease burden has resulted from chlorine-resistant oocysts of Cryptosporidium hominis or C. parvum [70]. Considerable research and management changes have been successful in reducing waterborne cryptosporidiosis from large municipal systems, and molecular methods are now available to identify the small subset of genotypes that are likely to be human infectious [71]. Nonetheless, QMRA estimates of waterborne cryptosporidiosis from small systems in developed regions is considerably higher than giardiasis, and possibly well above levels considered acceptable [72]. Therefore, C. parvum and/or C. hominis are generally the reference parasitic protozoan used in QMRA to assess and manage drinking waters. Unfortunately, most jurisdictions do not discriminate between the genotypes that may infect humans versus those that may not (as a precautionary principle), yet that decision may have major cost ramifications, and money could be better spent elsewhere to reduce drinking-water disease burden when the two key Cryptosporidium oocyst sources (human sewage or calf feces [73]) are not likely to impact source drinking waters.

Waterborne outbreaks from other parasitic protozoa appear to be rarer (e.g. Blastocystis hominis, Cyclospora cayetanensis, and Toxoplasma gondii) [74], and attention to Cryptosporidium control in watersheds, water treatment, and distribution should largely address these other members. Less well-understood are the microsporidia, once classified as parasitic protozoan and identified in some waterborne outbreaks [70]. Enterocytozoon bieneusi has been identified in source waters [73] and is considered the most common member among 17 human pathogenic microsporidian species that largely impact HIV/AIDS and immunosuppressed patients [75]. Taxonomically, the microsporidia are within the phylum Microspora, and are classified among spore-forming unicellular fungal parasites. As such, they produce smaller spores than the oo/cysts of parasitic protozoa, but due to likely low occurrence their movement through sand filtration processes [76] may be better modeled using bacterial spore surrogates, which are typically removed to a lesser degree than parasitic protozoan oo/cysts [77]. Zoonotic spread from bovines is considered important, although microsporidial infection rates in cattle are probably significantly lower than for Cryptosporidium spp. [78]. 


\section{Water-Based (Environmental) Pathogens}

Amoeba-Resisting Bacteria

Respiratory disease caused by NTM and L. pneumophila is the dominant hospitalization cost claim in the US, and largely results from drinking-water-related aerosol exposures [14•]. However, there has been slow recognition of this fact, due, in part, to the overlap in clinical findings of the severe form of pneumonia known as Legionnaires' disease with other more common causes of community-acquired pneumonia (CAP), noting that NTM also contribute to the health burden through wound and soft tissue infections, and P. aeruginosa via AMR infections in healthcare settings and, to a lesser degree, from folliculitis via pools and spas [79]. Looking at the legionellae first, despite Legionella micdadei being identified from blood in a CAP patient in 1943 it took the 1976 Legionnaires' disease epidemic in Philadelphia to fully recognize and describe L. pneumophila and Legionnaires' disease [80]. Indeed, retrospectively, the first documented epidemic of Legionnaires' disease was traced back to Austin, MN, USA, in the summer of 1957 [81]. However, legionellosis was only made a reportable disease in the US in 2001, with L. pneumophila causing $80-90 \%$ of identified cases in the US [16 ${ }^{\bullet}$ and worldwide [82], and with L. longbeacheae adding 2-7 \% of Legionnaires' disease cases, except in Australia where it accounted for approximately $30 \%$ [82]. A further complication results from the difficulty in culturing L. pneumophila, which requires the reduced forms of the amino acid cysteine and ferrous iron [83], and the likelihood of VBNC and other difficultto-culture cell forms [84] being dominant in drinking waters. One solution identified in the 1980s is to co-culture these problematic cell forms with free-living amoebae [85], as occurs in nature [86]. Follow-up identification can then use molecular methods targeting the $16 \mathrm{~S}$ rRNA gene and PCR directed to the macrophage infectivity potentiator (mip) gene to confirm L. pneumophila, with other genes (gyrA, rpoB, rnp B) also used to describe additional species [87].

The NTM are ubiquitous in freshwaters and are often the dominant group within drinking-water pipe biofilms, probably selected for by the presence of a residual disinfectant [88•]. Opportunistic members linked to drinking water infections include the Mycobacterium avium complex (which includes $M$. intracellulare), M. chelonae, M. fortuitum, $M$. gordonae, and M. kansasii [89]. However, care is needed to resolve between clinically important strains and nonpathogenic environmental members. Environmental isolates of clinically relevant species are often not identified as the etiologic agents. However, is this just a limit of our culture-based approaches or truly a misdiagnosis of the environmental source? Next-generation sequencing not reliant on culturing is likely to resolve such controversies with these water-based pathogens.
Most important to note is that L. pneumophila, NTM, and an increasing list of other amoeba-resisting bacteria (ARB) are opportunistic pathogens growing within drinking-water biofilms (Table 1). Chronic persistence of $A R B$ is particularly problematic to control in healthcare settings due to the ubiquitous nature of amoebae and the protection they confer on their intracellular pathogens [90]. Comparative genomics is also proving to be beneficial to identify human pathogenic members, such as key Legionella species [82].

\section{Free-Living Amoebae and Their Viruses}

Both culture- and molecular-based methods have identified the free-living amoebae Acanthamoeba, Naegleria, Protacanthamoeba spp. and Vermamoeba (formally Hartmannella) vermiformis. Less frequent detections include Echinamoeba, Vahlkampfia, and Vannella spp., amongst others, all likely environmental hosts of amoeba-resisting bacterial pathogens such as NTM and legionellae in drinking waters $[22,91 \cdot]$ (Table 1). Some of these free-living amoebae may be pathogens in their own right, such as those causing Acanthamoeba keratitis via drinking water, a serious eye infection primarily affecting contact lens users, although several cases have involved other genera (Vahlkampfia, Vannella, and Hartmannella spp.) [22]. More severe and often lifethreatening infections affecting immunocompetent children and immunocompromised adults include encephalitis involving Acanthamoeba spp. and Balamuthia mandrillaris, and Naegleria fowleri causing meningoencephalitis [22]. Nasal irrigation with drinking water from warm climatic zones has been identified as an important source of primary amoebic meningoencephalitis (PAM) caused by growth of $N$. fowleri through nasal passages to the brain [92]. Luckily, N. fowleri is readily controlled in drinking water by maintaining a disinfectant residual [93], remembering the main growth is thought to occur within biofilms, therefore biofilm control through minimization of stagnation zones and monitoring is also suggested for problematic climatic zones.

Acanthamoeba polyphaga mimivirus (APMV), first misidentified as a bacterium due to its large size $(>700 \mathrm{~nm}$ capsid), appears to be one of a group of giant viruses that infect aquatic and soil protozoa and metazoan [94]. They are environmentally very robust and some have been implicated in human cases of pneumonia [21]. Recent viral metagenomic studies have vastly increased the number of new members of the Megavirales order of giant viruses and their virophages [95], with new species of clinical significance expected.

\section{Control of Water-Based Pathogens}

A common feature of the water-based pathogens is the ability to grow to problematic concentrations within biofilms on pipe 
walls and sediments, particularly during periods of water stagnation and warmer conditions; therefore, control below some critical concentration is necessary to manage these environmental pathogens. For L. pneumophila, some millions of cells per liter of drinking water may be necessary so that aerosols of a respiratory size reach the alveoli and cause human infection [96]. Lesser concentrations, but some contact, are required for $P$. aeruginosa folliculitis [79]; the infective doses for NTM and $N$. fowleri are probably low but are undocumented.

Therefore, there are competing issues in managing all of these water-based pathogens, should they co-occur. Legionella and NTM of human health concern probably both grow within amoebae; therefore, limiting susceptible amoebae hosts by way of biofilm control seems logical, as would monitoring for total amoebae to evaluate control [97]. However, maintaining a high disinfectant residual may select for NTM biofilms that could contain problematic strains, although control $N$. fowleri. Some evidence suggests that monochloramine is effective against free and amoeba-cultured L. pneumophila, while chlorine and chlorine dioxide are less effective drinking-water disinfectants against amoeba-cultured pathogens, implying different modes of disinfection [98]. Of pipe materials, copper appears to develop less biofilm biomass, but select for VBNC L. pneumophila compared with PVC [99•, 100•], whereas cross-linked polyethylene appears to support both legionellae and M. avium complex as culturable cells at $40-55{ }^{\circ} \mathrm{C}$ [101]. Hence, keeping piped cold water cool $\left(<20{ }^{\circ} \mathrm{C}\right)$ and hot water $>60{ }^{\circ} \mathrm{C}$ via constant circulation seems to offer the most pragmatic control options for all of these pathogens within premise plumbing [15]. A speculative control approach is to maintain an actively antagonistic biofilm community that suppresses growth of members that may be opportunistic pathogens [102].

\section{Opportunistic Fungal Infections}

Of the filamentous fungi, Aspergillus fumigatus and A. terreus have been isolated from hospital drinking waters that caused nosocomial infections [103]. However, while fungal filaments are often observed in drinking-water biofilms, they are rarely identified. Recent next-generation sequencing of drinking-water biofilms has identified three opportunistic fungal pathogens-Candida albicans, C. parapsilosis, and Exophiala (formally Wangiella) dermatitidis [104]. It is noted that disseminated candidiasis caused by $C$. albicans is a leading nosocomial bloodstream infection in the US, with a high case fatality rate. E. dermatitidis is a ubiquitous black yeast that grows optimally around $40{ }^{\circ} \mathrm{C}$ and is most commonly seen in saunas, steam baths, and humidifiers [105].

\section{Conclusions}

With of advent of next-generation sequencing for routine clinical and environmental microbiology, there is renewed hope to improve upon identifying novel and currently known, but nondetected, physiological states of drinking water pathogens.

There is also intriguing new evidence that what were once thought of as strictly enteric pathogens may contain members with environmental amplification potential, ranging from human enteric viruses [34•] to $E$. coli $\mathrm{O} 157: \mathrm{H} 7$ [23•], but for now that is largely speculative. What is more concrete is the rising health burden resulting from opportunistic pathogens via drinking water [13], which are largely unregulated worldwide.

\section{Compliance with Ethics Guidelines}

Conflict of Interest Nicholas J. Ashbolt has a patent method for detection of viable Cryptosporidium parvum cells-Australian patent number 96/00274; EP0840799 A1 filed 6 May 1996, issued 13 May 1998 - and receives royalties.

Human and Animal Rights and Informed Consent This article does not contain any studies with human or animal subjects performed by the author.

Open Access This article is distributed under the terms of the Creative Commons Attribution License which permits any use, distribution, and reproduction in any medium, provided the original author(s) and the source are credited.

\section{References}

Papers of particular interest, published recently, have been highlighted as:

- Of importance

1. Hrudey SE, Hrudey EJ. Ensuring safe drinking water: learning from frontline experience with contamination. Denver (CO): American Water Works Association; 2014. Reviews key waterborne outbreaks and describes errors responsible.

2. Grandesso F, Allan M, Jean-Simon PS, Boncy J, Blake A, Pierre R, et al. Risk factors for cholera transmission in Haiti during inter-peak periods: insights to improve current control strategies from two case-control studies. Epidemiol Infect. 2014;142(8):1625-35.

3. Moore SM, Shannon KL, Zelaya CE, Azman AS, Lessler J. Epidemic risk from cholera introductions into Mexico. PLoS Curr. 2014;6. doi:10.1371/currents.outbreaks. c04478c7fbd9854ef6ba923cc81eb799. Edition 1.

4. Loharikar A, Newton AE, Stroika S, Freeman M, Greene KD, Parsons MB, et al. Cholera in the United States, 2001-2011: a reflection of patterns of global epidemiology and travel. Epidemiol Infect. 2014. doi:10.1017/S0950268814001186. Cholera surveillance that provides insight into global and United States trends.

5. World Health Organization. Water safety plan manual: step-bystep risk management for drinking-water suppliers. Geneva: World Health Organization; 2009. 
6. World Health Organization. Guidelines for drinking-water quality. 4th ed. Geneva: World Health Organization; 2011.

7. Ebacher G, Besner MC, Clément B, Prévost M. Sensitivity analysis of some critical factors affecting simulated intrusion volumes during a low pressure transient event in a full-scale water distribution system. Water Res. 2012;46(13):4017-30. Reviews DWDS intrusion events caused by transient low pressures that may result in drinking water contamination.

8. Lambertini E, Borchardt MA, Kieke Jr BA, Spencer SK, Loge FJ. Risk of viral acute gastrointestinal illness from nondisinfected drinking water distribution systems. Environ Sci Technol. 2012;46(17):9299-307. Epidemiology of non-disinfected DWDS that demonstrates virus intrusions can contribute to sporadic gastrointestinal illness.

9. Beaudeau P, Schwartz J, Levin R. Drinking water quality and hospital admissions of elderly people for gastrointestinal illness in Eastern Massachusetts, 1998-2008. Water Res. 2014;52:188-98.

10. Ford TE. Microbiological safety of drinking water: united states and global perspectives. Environ Health Perspect. 1999;107 Suppl 1:191-206.

11. Hellard ME, Sinclair MI, Forbes AB, Fairley CK. A randomized, blinded, controlled trial investigating the gastrointestinal health effects of drinking water quality. Environ Health Perspect. 2001;109(8):773-8.

12. Reynolds KA, Mena KD, Gerba CP. Risk of waterborne illness via drinking water in the United States. Rev Environ Contam Toxicol. 2008;192:117-58.

13. National Research Council. Drinking water distribution systems: assessing and reducing risks. Committee on Public Water Supply Distribution Systems: assessing and reducing risks. Water Science and Technology Board, Division on Earth and Life Studies, National Research Council of the National Academies. Washington, DC: The National Academies Press; 2006.

14. Collier SA, Stockman LJ, Hicks LA, Garrison LE, Zhou FJ, Beach MJ. Direct healthcare costs of selected diseases primarily or partially transmitted by water. Epidemiol Infect. 2012;140(11):200313. Legionnaires' disease, otitis externa, and non-tuberculous mycobacterial infections via drinking water exposures are more important than enteric waterborne hospitalizations, and are responsible for over 40,000 hospitalizations in the United States at a cost of $\$ 970$ million per year.

15. Sidari III FP, Stout JE, Duda S, Grubb D, Neuner A. Maintaining Legionella control in building water systems. J Am Water Works Assoc. 2014;106(10):24-32.

16. Craun GF, Brunkard JM, Yoder JS, Roberts VA, Carpenter J, Wade $\mathrm{T}$, et al. Causes of outbreaks associated with drinking water in the United States from 1971 to 2006. Clin Microbiol Rev. 2010;23(3): 507-28. Key summary of waterborne disease outbreaks in the US, identifying legionellosis as the highest health burden.

17. Exner M, Kramer A, Lajoie L, Gebel J, Engelhart S, Hartemann P. Prevention and control of health care-associated waterborne infections in health care facilities. Am J Infect Control. 2005;33(5):S26-40.

18. Leclerc H, Schwartzbrod L, Dei-Cas E. Microbial agents associated with waterborne diseases. Crit Rev Microbiol. 2002;28(4): 371-409.

19. Szewzyk U, Szewzyk R, Manz W, Schleifer KH. Microbiological safety of drinking water. Ann Rev Microbiol. 2000;54:81-127.

20. Medema G, Loret J-F, Stenström TA, Ashbolt N. Quantitative microbial risk assessment in the water safety plan. Final report on the EU MicroRisk Project. Brussels: European Commission. 2006. Available at: http://www.microrisk.com/publish/cat_index_11. shtml. Accessed 24 Dec 2014.

21. Dornas FP, Silva LC, de Almeida GM, Campos RK, Boratto PV, Franco-Luiz AP, et al. Acanthamoeba polyphaga mimivirus stability in environmental and clinical substrates: implications for virus detection and isolation. PLoS One. 2014;9(2):e87811.
22. Thomas V, McDonnel G, Denyer SP, Maillard J-Y. Freeliving amoebae and their intracellular pathogenic microorganisms: risk for water quality. FEMS Microbiol Rev. 2010;34:231-59.

23. Sales-Ortells H, Medema G. Screening-level microbial risk assessment of urban water locations: a tool for prioritization. Environ Sci Technol. 2014;48(16):9780-9. Demonstration of how to undertake QMRA to model event and annual probability of gastrointestinal illness and Legionnaires' disease using selected literature data.

24. Gourabathini P, Brandl MT, Redding KS, Gunderson JH, Berk SG. Interactions between food-borne pathogens and protozoa isolated from lettuce and spinach. Appl Environ Microbiol. 2008;74(8):2518-25.

25. Juhna T, Birzniece D, Larsson S, Zulenkovs D, Sharipo A, Azevedo NF, et al. Detection of Escherichia coli in biofilms from pipe samples and coupons in drinking water distribution networks. Appl Environ Microbiol. 2007;73(22):7456-64.

26. Soller JA, Bartrand T, Ashbolt NJ, Ravenscroft J, Wade TJ. Estimating the primary etiologic agents in recreational freshwaters impacted by human sources of faecal contamination. Water Res. 2010;44(16):4736-47.

27. Smeets PW, Rietveld LC, van Dijk JC, Medema GJ. Practical applications of quantitative microbial risk assessment (QMRA) for water safety plans. Water Sci Technol. 2010;61(6):1561-8.

28. Borchardt MA, Spencer SK, Kieke BA, Lambertini E, Loge FJ. Viruses in nondisinfected drinking water from municipal wells and community incidence of acute gastrointestinal illness. Environ Health Perspect. 2012;120(9):1272-9.

29. Schijven JF, Teunis PF, Rutjes SA, Bouwknegt M, Husman AM. QMRAspot: a tool for quantitative microbial risk assessment from surface water to potable water. Water Res. 2011;45(17):5564-76.

30. Liu G, Bakker GL, Li S, Vreeburg JH, Verberk JQ, Medema GJ, et al. Pyrosequencing reveals bacterial communities in unchlorinated drinking water distribution system: an integral study of bulk water, suspended solids, loose deposits, and pipe wall biofilm. Environ Sci Technol. 2014;48(10):5467-76.

31. Szabo J, Minamyer S. Decontamination of biological agents from drinking water infrastructure: a literature review and summary. Environ Int. 2014;72:124-8.

32. Loret JF, Greub G. Free-living amoebae: biological by-passes in water treatment. Int J Hyg Environ Health. 2010;213(3):167-75.

33. Storey MV, Ashbolt NJ. Enteric virions and microbial biofilms: a secondary source of public health concern. Water Sci Technol. 2003;48(3):97-104.

34. Bichai F, Dullemont Y, Hijnen W, Barbeau B. Predation and transport of persistent pathogens in GAC and slow sand filters: a threat to drinking water safety? Water Res. 2014;64:296-308. Excellent summary of zooplankton aiding transport of internalized enteric pathogens through engineered drinking water systems.

35. Scheid P, Schwarzenberger R. Acanthamoeba spp. as vehicle and reservoir of adenoviruses. Parasitol Res. 2012;111(1):479-85.

36. Ahmed SM, Hall AJ, Robinson AE, Verhoef L, Premkumar P, Parashar UD, et al. Global prevalence of norovirus in cases of gastroenteritis: a systematic review and meta-analysis. Lancet Infect Dis. 2014;14(8):725-30. Review of norovirus gastroenteritis that indicates it is the key pathogen associated with almost onefifth of all cases of acute gastroenteritis.

37. Matthews JE, Dickey BW, Miller RD, Felzer JR, Dawson BP, Lee AS, et al. The epidemiology of published norovirus outbreaks: a review of risk factors associated with attack rate and genogroup. Epidemiol Infect. 2012;140(7):1161-72.

38. Tan M, Jiang X. Histo-blood group antigens: a common niche for norovirus and rotavirus. Expert Rev Mol Med. 2014;16:e5.

39. Jones MK, Watanabe M, Zhu S, Graves CL, Keyes LR, Grau KR, et al. Enteric bacteria promote human and mouse norovirus infection of B cells. Science. 2014;346(6210):755-9. First demonstration of human and mouse noroviruses in vitro and likely in vivo 
infection of B cells, opening a possible way to test water disinfection efficacy for these previously unculturable viruses.

40. Li D, De Keuckelaere A, Uyttendaele M. Application of long-range and binding reverse transcription-quantitative PCR to indicate the viral integrities of noroviruses. Appl Environ Microbiol. 2014;80(20):6473-9.

41. Cromeans T, Park GW, Costantini V, Lee D, Wang Q, Farkas T, et al. Comprehensive comparison of cultivable norovirus surrogates in response to different inactivation and disinfection treatments. Appl Environ Microbiol. 2014;80(18):5743-51. Evaluation of cultivable surrogate viruses for human noroviruses, including feline calicivirus, murine norovirus, porcine enteric calicivirus, and Tulane virus.

42. Messner MJ, Berger P, Nappier SP. Fractional poisson: a simple dose-response model for human norovirus. Risk Anal. 2014;34(10):1820-9. Evaluation of old and new norovirus human challenge data to model the dose-response relationship for human norovirus infection.

43. Teunis PF, Xu M, Fleming KK, Yang J, Moe CL, LeChevallier MW. Enteric virus infection risk from intrusion of sewage into a drinking water distribution network. Environ Sci Technol. 2010;44(22):8561-6.

44. Grøndahl-Rosado RC, Yarovitsyna E, Trettenes E, Myrmel M, Robertson LJ. A one year study on the concentrations of Norovirus and enteric adenoviruses in wastewater and a surface drinking water Source in Norway. Food Environ Virol. 2014. doi:10.1007/s12560-014-9161-5.

45. Hata A, Katayama H, Kojima K, Sano S, Kasuga I, Kitajima M, et al. Effects of rainfall events on the occurrence and detection efficiency of viruses in river water impacted by combined sewer overflows. Sci Total Environ. 2014;468-469:757-63.

46. Sedmak G, Bina D, Macdonald J, Couillard L. Nine-year study of the occurrence of culturable viruses in source water for two drinking water treatment plants and the influent and effluent of a wastewater treatment plant in Milwaukee, Wisconsin (August 1994 through July 2003). Appl Environ Microbiol. 2005;71(2):1042-50.

47. Rodriguez RA, Bounty S, Beck S, Chan C, McGuire C, Linden KG. Photoreactivation of bacteriophages after UV disinfection: Role of genome structure and impacts of UV source. Water Res. 2014;55C:143-9. Provides key data on bacteriophage model viruses to assess UV disinfection of adenovirus, noting genome organization differences between phages and their bacterial host's repair mechanisms play important roles in resistance to UV inactivation.

48. Ashbolt NJ, Grabow WOK, Snozzi M. Indicators of microbial water quality. In: Fewtrell L, Bartram J, editors. Water quality: guidelines, standards and health. Risk assessment and risk management for water-related infectious disease. London: IWA Publishing; 2001. p. 289-315.

49. Ashbolt NJ, Schoen ME, Soller JA, Roser DJ. Predicting pathogen risks to aid beach management: the real value of quantitative microbial risk assessment (QMRA). Water Res. 2010;44(16):4692-703.

50. Coleman BL, Louie M, Salvadori MI, McEwen SA, Neumann N, Sibley K, et al. Contamination of Canadian private drinking water sources with antimicrobial resistant Escherichia coli. Water Res. 2013;47(9):3026-36.

51. Ashbolt NJ, Amézquita A, Backhaus T, Borriello SP, Brandt K, Collignon $\mathrm{P}$, et al. Human health risk assessment (HHRA) for environmental development and transfer of antibiotic resistance. Environ Health Perspect. 2013;121(9):993-1001. Review of issues and way forward to enable a QMRA approach to assess environmental antimicrobial resistance impacts.

52. Harrison EM, Weinert LA, Holden MT, Welch JJ, Wilson K, Morgan FJ, et al. A shared population of epidemic methicillinresistant Staphylococcus aureus 15 circulates in humans and companion animals. AmBio. 2014;5(3):e00985-13.
53. Angulo FJ, Tippen S, Sharp DJ, Payne BJ, Collier C, Hill JE, et al. A community waterborne outbreak of Salmonellosis and the effectiveness of a boil water order. Am J Public Health. 1997;87(4):580-4.

54. Hrudey SE, Huck PM, Payment P, Gillham RW, Hrudey EJ. Walkerton: Lessons learned in comparison with waterborne outbreaks in the developed world. J Environ Eng Sci. 2002;1(6):397-407.

55. Pitkänen T. Review of Campylobacter spp. in drinking and environmental waters. J Microbiol Meth. 2013;95(1):39-47.

56. Sen K, Ashbolt NJ. Environmental microbiology: current technology and water applications. Norfolk: Caister Academic Press; 2011.

57. Haugland RA, Siefring SD, Varma M, Dufour AP, Brenner KP, Wade TJ, et al. Standardization of enterococci density estimates by EPA qPCR methods and comparison of beach action value exceedances in river waters with culture methods. J Microbiol Meth. 2014;105C:59-66. Description of the first US EPA qPCR method for microbiological evaluation of water quality.

58. US Environmental Protection Agency. Recreational water quality criteria. Office of Water Report 820-F-12-058. Washington, DC: US Environmental Protection Agency; 2012. Key summary of recent epidemiologic studies of bathing water gastrointestinal illness from fecally-contaminated recreational waters, and identification of qPCR as the preferred index of health outcome.

59. Pitkänen T, Ryu H, Elk M, Hokajärvi AM, Siponen S, Vepsäläinen A, et al. Detection of fecal bacteria and source tracking identifiers in environmental waters using rRNA-based RT-qPCR and rDNAbased qPCR assays. Environ Sci Technol. 2013;47(23):13611-20. Initial study demonstrating the improved detection sensitivity and likely viability of FIB by targeting ribosomal RNA rather than DNA by qPCR of environmental water samples.

60. Li L, Mendis N, Trigui H, Oliver JD, Faucher SP. The importance of the viable but non-culturable state in human bacterial pathogens. Front Microbiol. 2014;5:258. Summary of VBNC state common to many bacterial pathogens and indicators, identifying conditions and mechanisms underlying what triggers its induction and cell resuscitation to culturability.

61. Bullman S, O'Leary J, Corcoran D, Sleator RD, Lucey B. Molecular-based detection of non-culturable and emerging campylobacteria in patients presenting with gastroenteritis. Epidemiol Infect. 2012;140(4):684-8.

62. Liu Y, Wang C, Tyrrell G, Li XF. Production of Shiga-like toxins in viable but nonculturable Escherichia coli O157:H7. Water Res. 2010;44(3):711-8.

63. Vaerewijck MJM, Baré J, Lambrecht E, Sabbe K, Houf K. Interactions of foodborne pathogens with free-living protozoa: potential consequences for food safety. Compr Rev Food Sci Food Saf. 2014;13(5):924-44.

64. Signoretto C, Burlacchini G, Pruzzo C, Canepari P. Persistence of Enterococcus faecalis in aquatic environments via surface interactions with copepods. Appl Environ Microbiol. 2005;71(5):2756-61.

65. Lewis K. Persister cells, dormancy and infectious disease. Nat Rev Microbiol. 2007;5(1):48-56.

66. Jensen JN. Disinfection model based on excess inactivation sites: implications for linear disinfection curves and the Chick-Watson dilution coefficient. Environ Sci Technol. 2010;44(21):8162-8.

67. Watson CL, Owen RJ, Said B, Lai S, Lee JV, Surman-Lee S, et al. Detection of Helicobacter pylori by PCR but not culture in water and biofilm samples from drinking water distribution systems in England. J Appl Microbiol. 2004;97(4):690-8.

68. Moreno Y, Piqueres P, Alonso JL, Jiménez A, Gonzállez A, Ferrús MA. Survival and viability of Helicobacter pylori after inoculation into chlorinated drinking water. Water Res. 2007;41(15): 3490-6.

69. Travis PB, Goodman KJ, O'Rourke KM, Groves FD, Sinha D, Nicholas JS, et al. The association of drinking water quality and sewage disposal with Helicobacter pylori incidence in infants: the 
potential role of water-borne transmission. J Water Health. 2010;8(1):192-203.

70. Karanis P, Kourenti C, Smith H. Waterborne transmission of protozoan parasites: a worldwide review of outbreaks and lessons learnt. J Water Health. 2007;5(1):1-38.

71. Hunter PR, de Sylor MA, Risebro HL, Nichols GL, Kay D, Hartemann P. Quantitative microbial risk assessment of cryptosporidiosis and giardiasis from very small private water supplies. Risk Anal. 2011;31(2):228-36.

72. Xiao L. Molecular epidemiology of cryptosporidiosis: an update. Exp Parasitol. 2010;124(1):80-9.

73. Dowd SE, Gerba CP, Pepper IL. Confirmation of the humanpathogenic microsporidia Enterocytozoon bieneusi, Encephalitozoon intestinalis, and Vittaforma corneae in water. Appl Environ Microbiol. 1998;64(9):3332-5.

74. Yang R, Murphy C, Song Y, Ng-Hublin J, Estcourt A, Hijjawi N. Specific and quantitative detection and identification of Cryptosporidium hominis and C. parvum in clinical and environmental samples. Exp Parasitol. 2013;135(1):142-7.

75. Didier ES, Weiss LM. Microsporidiosis: not just in AIDS patients. Curr Opin Infect Dis. 2011;24(5):490-5.

76. Brusseau ML, Oleen JK, Santamaria J, Cheng L, Orosz-Coghlan P, Chetochine AS, et al. Transport of microsporidium Encephalitozoon intestinales spores in sandy porous media. Water Res. 2005;39(15):3636-42.

77. Hijnen WAM, Medema GJ. Elimination of micro-organisms by drinking water treatment processes: a review. Thirdth ed. London: IWA Publishing; 2010. p. 160.

78. Ma J, Li P, Zhao X, Xu H, Wu W, Wang Y, et al. Occurrence and molecular characterization of Cryptosporidium spp. and Enterocytozoon bieneusi in dairy cattle, beef cattle and water buffaloes in China. Vet Parasitol. 2014. doi:10.1016/j.vetpar.2014.10.011.

79. Roser DJ, van den Akker B, Boase S, Haas CN, Ashbolt NJ, Rice SA. Dose-response algorithms for water-borne Pseudomonas aeruginosa folliculitis. Epidemiol Infect. 2014. doi:10.1017/ S0950268814002532:1-14.

80. Edelstein PH. Legionnaires' disease: history and clinical findings. In: Heuner K, Swanson MS, editors. Legionella: molecular microbiology. Norfolk: Caister Academic Press; 2008.

81. Osterholm MT, Chin TD, Osborne DO, Dull HB, Dean AG, Fraser DW, et al. A 1957 outbreak of Legionnaires' disease associated with a meat packing plant. Am J Epidemiol. 1983;117(1):60-7.

82. Gomez-Valero L, Rusniok C, Rolando M, Neou M, DervinsRavault D, Demirtas J, et al. Comparative analyses of Legionella species identifies genetic features of strains causing Legionnaires' disease. Genome Biol. 2014;15(11):505.

83. Devos L, Boon N, Verstraete W. Legionella pneumophila in the environment: occurrence of a fastidious bacterium in oligotrophic conditions. Rev Environ Sci Biotechnol. 2005;4(1):61-74.

84. Garduño RA, Garduño E, Hiltz M, Hoffman PS. Intracellular growth of Legionella pneumophila gives rise to a differentiated form dissimilar to stationary-phase forms. Infect Immun. 2002;70(11):6273-83.

85. Rowbotham TJ. Isolation of Legionella pneumophila from clinical specimens via amoebae, and the interaction of those and other isolates with amoebae. J Clin Pathol. 1983;36(9):978-86.

86. Price CT, Richards AM, Von Dwingelo JE, Samara HA, Abu Kwaik Y. Amoeba host-Legionella synchronization of amino acid auxotrophy and its role in bacterial adaptation and pathogenic evolution. Environ Microbiol. 2014;16(2):350-8.

87. Luck PC, Jacobs E, Roske I, Schroter-Bobsin U, Dumke R, Gronow S. Legionella dresdenensis sp. nov., isolated from river water. Int J Syst Evol Microbiol. 2010;60(Pt 11):2557-62.

88. Wang H, Masters S, Edwards MA, Falkinham 3rd JO, Pruden A. Effect of disinfectant, water age, and pipe materials on bacterial and eukaryotic community structure in drinking water biofilm. Environ Sci Technol. 2014;48(3):1426-35. Describes, via metagenomic analysis, the impacts of disinfectant (chloramines, chlorine), water age (2.3 days, 5.7 days), and pipe material (cement, iron, $P V C$ ) on the microbiome of drinking-water biofilms.

89. Falkinham 3rd JO. Hospital water filters as a source of Mycobacterium avium complex. J Med Microbiol. 2010;59(Pt 10):1198-202.

90. Cateau E, Delafont V, Hechard Y, Rodier MH. Free-living amoebae: what part do they play in healthcare-associated infections? J Hosp Infect. 2014;87(3):131-40.

91. Delafont V, Brouke A, Bouchon D, Moulin L, Hechard Y. Microbiome of free-living amoebae isolated from drinking water. Water Res. 2013;47(19):6958-65. Using 16S and 18S ribosomal $R N A$-directed sequencing of drinking water biofilms demonstrated Hartmannella (Vermamoeba) as the predominant free-living amoebal genus, and identified 54 amoebae-resisting bacteria, of which 21 are newly described.

92. Yoder JS, Straif-Bourgeois S, Roy SL, Moore TA, Visvesvara GS, Ratard RC, et al. Primary amebic meningoencephalitis deaths associated with sinus irrigation using contaminated tap water. Clin Infect Dis. 2012;55(9):e79-85.

93. Trolio R, Bath A, Gordon C, Walker R, Wyber A. Operational management of Naegleria spp in drinking water supplies in Western Australia. Water Sci Technol Water Supply. 2008;8(2): 207-15.

94. Abrahao JS, Dornas FP, Silva LC, Almeida GM, Boratto PV, Colson $\mathrm{P}$, et al. Acanthamoeba polyphaga mimivirus and other giant viruses: an open field to outstanding discoveries. Virol J. 2014;11(1):120.

95. Boughalmi M, Saadi H, Pagnier S, Colson P, Fournous G, Raoult $\mathrm{D}$, et al. High-throughput isolation of giant viruses of the Mimiviridae and Marseilleviridae families in the Tunisian environment. Environ Microbiol. 2013;15(7):2000-7.

96. Schoen ME, Ashbolt NJ. An in-premise model for Legionella exposure during showering events. Water Res. 2011;45(18):5826-36.

97. Codony F, Pérez LM, Adrados B, Agustí G, Fittipaldi M, Morató J. Amoeba-related health risk in drinking water systems: could monitoring of amoebae be a complementary approach to current quality control strategies? Future Microbiol. 2012;7(1):25-31.

98. Dupuy M, Mazoua S, Berne F, Bodet C, Garrec N, Herbelin P, et al. Efficiency of water disinfectants against Legionella pneumophila and Acanthamoeba. Water Res. 2011;45(3):1087-94.

99. Lu J, Buse H, Gomez-Alvarez V, Struewing I, Santo Domingo J, Ashbolt NJ. Impact of drinking water conditions and copper materials on downstream biofilm microbial communities and Legionella pneumophila colonization. J Appl Microbiol. 2014;117(3):905-18. This article is a demonstration that the different biofilm microbiomes developed on upstream copper versus PVC coupons influenced the biofilm communities grown downstream on a third (Norprene) surface material, including a copper bias to support L. pneumophila.

100. Buse HY, Lu J, Lu X, Mou X, Ashbolt NJ. Microbial diversities (16S and 18S rRNA gene pyrosequencing) and environmental pathogens within drinking water biofilms grown on the common premise plumbing materials unplasticized polyvinylchloride and copper. FEMS Microbiol Ecol. 2014;88(2):280-95. Using 165 and $18 S$ rRNA pyrosequencing demonstrated that 1-year-old drinking water biofilms on copper prolonged the development of L. pneumophila, which was further increased by the presence of Acanthamoeba compared with 1-year-old PVC coupon biofilms that supported more biomass.

101. Bukh AS, Roslev P. Mycobacterium avium complex in day care hot water systems, and persistence of live cells and DNA in hot water pipes. Curr Microbiol. 2014;68(4):428-39.

102. Wang H, Edwards MA, Falkinham 3rd JO, Pruden A. Probiotic approach to pathogen control in premise plumbing systems? A review. Environ Sci Technol. 2013;47(18):10117-28. 
103. Anaissie EJ, Penzak SR, Dignani MC. The hospital water supply as a source of nosocomial infections: a plea for action. Arch Intern Med. 2002;162(13):1483-92.

104. Heinrichs G, Hubner I, Schmidt CK, de Hoog GS, Haase G. Analysis of black fungal biofilms occurring at domestic water taps. I: compositional analysis using Tag-Encoded FLX
Amplicon Pyrosequencing. Mycopathologia. 2013;175(5-6): 387-97.

105. Matos T, de Hoog GS, de Boer AG, de Crom I, Haase G. High prevalence of the neurotrope Exophiala dermatitidis and related oligotrophic black yeasts in sauna facilities. Mycoses. 2002;45(910):373-7. 